Irena Srdanović, Dragana Špica

\title{
Sudjelovanje studenata japanskog jezika u leksikografskim aktivnostima i planiranje bilingvalnog e-rječnika
}

Originalni znastveni rad

Original scientific paper

UDK 811.521'342-378

https://doi.org/10.32728/tab.18.2021.9

\section{SAŽETAK}

Većina studenata japanologije na Sveučilištu Jurja Dobrile u Puli pripada generaciji digitalnih urođenika (engl. digital natives), a njihovoj digitalnoj pismenosti dodatno doprinosi i dostupnost velikoga broja resursa japanskoga jezika, što u obliku aplikacija na pametnim telefonima i mobitelima što u obliku internetskih stranica, računalno potpomognutih alata za učenje jezika i drugih multimedijalnih alata. Kako većina ovih resursa koristi japanski i engleski jezik, primjećuje se potreba studenata za dvojezičnim rječnicima i drugim izvorima za japanski jezik s objašnjenjima, prijevodima i dodatnim informacijama na njihovom materinskom jeziku. Cilj je ovoga rada dvostruk: 1) predstaviti pilot-projekte izrade japansko-hrvatskih dvojezičnih e-rječnika u suradnji studenata i nastavnika Sveučilišta Jurja Dobrile u Puli i uz pomoć otvorene platforme za izradu e-rječnika Lexonomy (Měchura 2017), 2) analizom provedene ankete utvrditi tendencije korištenja postojećih rječnika, elektroničkih rječnika i drugih resursa kao i potrebe učenika japanskoga jezika za planiranim opsežnijim japansko-hrvatskim e-rječnikom u svrhu izrade modela toga e-rječnika.

Ključne riječi: japansko-hrvatski dvojezični rječnik, e-rječnik, anketa, digitalni resursi, studenti japanologije 


\section{UVOD}

Napredak tehnologije praćen je novim generacijama učenika koje Prensky (2001) naziva „digital natives“ (hrv. digitalni urođenici), što se odnosi na osobe rođene nakon 1980. godine koje su odrasle uz najnovije tehnologije, mobitel, videoigrice i društvene mreže. Većina studenata japanologije na Sveučilištu Jurja Dobrile u Puli pripada ovoj generaciji, a svoju digitalnu pismenost razvijaju i korištenjem raznovrsnim slobodno dostupnim resursima japanskoga jezika, što uključuje aplikacije na pametnim telefonima i mobitelima, internetske stranice s e-rječnicima, e-rječničkim serverima, računalno potpomognutim alatima za učenje jezika i druge multimedijalne alate. S druge strane, većina njihovih nastavnika pripada grupi tzv. „digitalnih pridošlica“ (engl. digital immigrants), generaciji kojoj su internet i najnovije tehnologije ušle u život nešto kasnije, ali većinom dovoljno rano da se na njih privikavaju i koriste ih po potrebi (Prensky 2001). U ovome radu opisujemo rezultate suradnje obiju generacija u više leksikografskih aktivnosti usmjerenih na studente japanskoga jezika te propitujemo navike korištenja digitalnih resursa kao i potrebe studenata japanskoga jezika za dvojezičnim rječnikom.

Kako većina gore spomenutih resursa koristi japanski i engleski jezik, primjećuje se potreba studenata za dvojezičnim rječnicima i drugim izvorima za japanski jezik s objašnjenjima, prijevodima i dodatnim informacijama na njihovom materinskom jeziku. Ta je potreba postala veća s porastom zanimanja za učenje japanskoga jezika u posljednjem desetljeću, praćena osnivanjem prvoga sveučilišnog studija japanologije u Hrvatskoj. Prema podatcima Japanske fondacije, 2015. godine u Hrvatskoj je bilo 175 učenika japanskoga, dok se taj broj 2018. uvećao na 199, računajući sve obrazovne institucije i škole stranih jezika. ${ }^{1} \mathrm{U}$ slučaju hrvatskoga i srodnih jezika, već neko vrijeme dostupni su jednostavniji rječnici manjeg obujma s relativno ograničenim brojem unosa i bez podataka o kolokacijama, primjerima upotrebe riječi ili bilo kojim drugim detaljnim informacijama koje učenici obično zahtijevaju. Prvi tiskani japansko-hrvatsko-japanski rječnik(YamasakiVukelić 2006) nastao je na osnovi japansko-srpskoga i srpsko-japanskoga izdanja. Ovaj rječnik sadrži nešto više od 12000 natuknica jednostavnije strukture, npr. bez kolokacija, primjera i drugih detaljnijih informacija. Osim toga, u mrežnom alatu za pomoć u čitanju i analizi japanskih tekstova Reading

1 Stranice Japanske fondacije:

https://www.jpf.go.jp/j/project/japanese/survey/result/dl/survey_2015/spreadsheet.pdf https://www.jpf.go.jp/j/project/japanese/survey/result/dl/survey2018/spreadsheet.pdf 
Tutor $^{2}$ uključen je isto manji broj japanskih riječi sa značenjima i prijevodom na hrvatski jezik. Manji japansko-hrvatski glosari dostupni su u okviru udžbenika - popis vokabulara u okviru hrvatskoga izdanja udžbenika Minna no Nihongo, kao i popis riječi koji postoji i u prvome japanskom udžbeniku na hrvatskome jeziku Ippo Ippo (Marković i dr. 2018). Odnedavno su na volju i e-rječnici značajnijeg obujma i sadržaja za mnogobrojne jezike uključujući japanski i hrvatski koji su nastali prikupljanjem podataka iz više baza poput korpusa, projekta Wictionary, FreeDic projekta i sličnih (npr. Glosbe, Lingea) ${ }^{3}$, što ukazuje na značaj novih tehnologija u izradi e-rječnika. Ovo su u ovome trenutku ili komercijalni projekti sa slobodnim pristupom ograničenom dijelu rječnika ili su popraćeni reklamnim sadržajem koji donekle otežava slobodno korištenje te ne bi bilo dovoljno osloniti se na njih, posebno iz perspektive učenika stranoga jezika kojima su potrebne i dodatne prilagođene funkcije. U slučaju japansko-slovenskoga dvojezičnog para, duži niz godina radi se na izradi e-rječnika jaSlo koji je namijenjen slovenskim učenicima japanskoga jezika. Ovaj je rječnik također manjega opsega, ima oko 10000 natuknica, $s$ detaljnom mikrostrukturom, poveznicama na podatke paralelnoga korpusa i podatke iz mrežnoga korpusa (Erjavec i dr. 2006; Hmeljak Sangawa i Erjavec 2010) te je naknadno bio povezan s gore spomenutim alatom Reading Tutor.

U skladu s navedenom potrebom za resursima na materinskome jeziku, koji su prilagođeni potrebama studenata japanskoga jezika, cilj je ovoga rada dvostruk: 1) predstaviti preliminarne pilot-projekte izrade japanskohrvatskih dvojezičnih e-rječnika u koje su uključeni studenti i nastavnici japanologije na Sveučilištu Jurja Dobrile u Puli, 2) analizom provedene ankete utvrditi tendencije korištenja postojećih rječnika, elektroničkih rječnika i drugih resursa kao i potrebe studenata za planiranim opsežnijim japansko-hrvatskim e-rječnikom.

\section{PRELIMINARNI LEKSIKOGRAFSKI PILOT-PROJEKTI}

Leksikografska teorija i praksa upućuju na značaj poučavanja leksikologije i leksikografije i angažiranja studenata u mini projekte (vidi npr. Sinclair 1984; Prćić 2020), pri čemu se u procesu poučavanja i učenja teži kombiniranju teorijskih i praktičnih aspekata izrade i korištenja rječnika. Na radionici

2 Alat je dostupan na sljedećoj stranici: https://chuta.cegloc.tsukuba.ac.jp/

3 https://ja.glosbe.com/, www.lingea.com (https://www.dict.com/japansko-hrvatski) Na stranici Lingea, Japansko-hrvatski rječnik Advanced, verzija 2.2 iz 2020. godine sadrži 14200 natuknica, 5600 primjera, 36100 prijevoda, (C) Lingea s.r.o., 2020. 
o budućnosti rječnika 2018. godine sastavljene su tzv. Villa Vigoni teze o leksikografiji ${ }^{4} \mathrm{~s}$ osvrtom na izazove koji se postavljaju pred izradom rječnika u digitalnome društvu. Među tezama se navodi potreba za aktivnim uključivanjem sveučilišta i javnih istraživačkih institucija u „kritičke rasprave i vrednovanje leksičkih informacijskih sustava“", kao i da „leksikografija treba razvijati koncepte koji omogućuju produktivno sudjelovanje korisnika u leksikografskim informacijskim sustavima".6 U skladu s ovim načelima osmišljen je kolegij na preddiplomskome studijskom programu japanologije u Puli, u okviru kojega su se studenti najprije upoznali s teorijom leksikologije i leksikografije, a zatim aktivno sudjelovali u nekoliko pilot-projekata dvojezičnih rječnika, postajući tako ne samo korisnici već i sukreatori bilingvalnog rječnika. ${ }^{7}$

\subsection{Upoznavanje studenata s leksikografskim radom i tehnologijama}

Kolegij Uvod u leksikologiju i leksikografiju bio je u ponudi tijekom akademskih godina 2017./2018. i 2018./2019. za studente treće godine preddiplomskoga sveučilišnog programa japanskoga jezika i kulture. ${ }^{8}$ Izvodio se jedanput tjedno dva školska sata u trajanju od 90 minuta tijekom 15 tjedana u semestru te je iznosio 4 ECTS-a. Cilj je kolegija definirati i objasniti osnovna načela opće i japanske leksikologije i leksikografije te primijeniti znanje u kreiranju i analizi rječnika koristeći se novim tehnologijama. Kolegij pokriva sljedeće sadržaje: Jezik kao fenomen, jezični varijeteti i pristupi analizi jezika; Uvod u leksikologiju i leksikografiju; Tipovi rječnika; Sadržaj rječnika i odluke prilikom izrade rječnika; Značenje riječi; Korpusna leksikografija; Elektronički rječnici i alati; Alat za uređivanje rječnika; Praktični rad.

4 Radionica je organizirana u prosincu 2018. godine s naslovom „Dictionaries for the Future - The Future of Dictionaries. Challenges for lexicography in a digital society" te su napisane smjernice o budućnosti rječnika u digitalnomu dobu. Teze Villa Vigoni o leksikografiji (Villa Vigoni thesis on lexicography) dostupne su na poveznici: https://www.emlex.phil.fau.eu/about-us/publications/other/.

5 „Universities and public research institutions as independent social institutions must actively participate in the critical discussions and evaluations of lexical information systems." (Villa Vigoni teze 2018) (prijevod autorice članka)

6 „Lexicography is called upon to develop concepts for productive user participation in lexicographic information systems." (Villa Vigoni teze 2018) (prijevod autorice članka)

7 Prva autorica ovoga rada predstavila je sadržaj pilot leksikografskih projekata i ideju o dvojezičnome japansko-hrvatskom rječniku na međunarodnom simpoziju „Učenje japanskog jezika za nove generacije" (Srdanović 2018).

8 Od akademske godine 2020./2021. odabrani sadržaji kolegija izvode se u prilagođenome obliku na prvoj godini diplomskoga studija pod naslovom „Japanska korpusna lingvistika, leksikologija i jezične tehnologije“. 
U okviru kolegija studenti se najprije upoznaju s osnovama korpusne leksikografije i različitim korpusima japanskoga jezika, nakon čega im se predstave različiti alati za pretraživanje korpusa. Jedan je od alata sa širokom primjenom u korpusnoj leksikografiji Sketch Engine (Kilgarriff i dr. 2004) u kojemu su dostupni i korpusi japanskoga jezika (Srdanović i dr. 2008; Srdanović i dr. 2012). Studenti se upoznaju s alatom i korpusima najprije kroz demonstraciju na satu, a zatim i kroz niz aktivnosti i samostalnih zadataka koji uključuju pretraživanje konkordančnika, skica riječi i usporednih skica riječi, napredne tehnologije za gradnju korpusa, korištenje tezaurusom, GDEX-om (Good Dictionary Examples) (Srdanović i Kosem 2016; Srdanović 2019) i ostalim funkcionalnostima. Uz to, studenti se na satu upoznaju s otvorenom platformom za uređivanje e-rječnika, Lexonomy (Měchura 2017), koji se nakon toga koristi za planiranje unutarnje mikrostrukture rječnika kao i prikaz rječnika. Unutar ovoga zadatka studenti su vođenim timskim radom definirali interna pravila i način zapisivanja natuknica s ciljem postizanja dosljednosti pri uređivanju rječnika, nakon čega su unosili nove natuknice u japansko-hrvatski pilot-rječnik (Srdanović 2018).

Ishodi ovoga kolegija na japanološkome studiju su: 1. Pravilno razumjeti temeljne pojmove iz područja leksikologije i leksikografije; 2. Primijeniti korpuse, pretraživače i druge alate za analizu japanskoga jezika i potrebe izrade rječnika; 3. Prepoznati i definirati ključne elemente mikrostrukture i makrostrukture rječnika; 4. Vrednovati leksikografske opise u postojećim jednojezičnim, dvojezičnim i višejezičnim rječnicima japanskoga jezika i znati ih usporediti s rezultatima iz jezičnih korpusa; 5. Izraditi manji korpus japanskoga jezika iz odabranoga područja; 6 . Sastaviti nove natuknice u e-rječniku uz korištenje podataka iz korpusa. Oni pomažu studentima bolje razumjeti što se očekuje u ovome kolegiju te za što će biti na kraju kolegija osposobljeni. ${ }^{9}$

\subsection{Praktični rad sa studentima i mini leksikografski projekti}

Nakon savladavanja osnovnih znanja i vještina, studenti su pristupili različitim praktičnim aktivnostima u okviru kolegija te aktivno sudjelovali u mini leksikografskim projektima. Među ponuđenim praktičnim aktivnostima bile su sljedeće (Srdanović 2018):

9 Željka Kamemov (2015), Usklađivanje ishoda učenja i metoda vrednovanja u visokoškolskim kolegijima:

https://www.srce.unizg.hr/files/srce/docs/CEU/TALOE/Ishodi_kolegija_SRCE.pdf 
- Vrednovanje opisa u japanskim rječnicima i mrežnim poslužiteljima s više različitih rječnika (engl. dictionary servers)

- Sastavljanje korpusa o hrvatskome turizmu na japanskome jeziku, analiza i priprema specijaliziranoga rječnika iz područja turizma

- Japanski idiomi i poslovice, njihova korpusna analiza i opis na hrvatskome jeziku

- Usporedna leksička analiza hrvatskoga i japanskoga jezika

- Detaljna analiza pridjeva i njihovih kolokacija (jedan student - jedan pridjev)

- Japansko-hrvatski rječnik s analizom korpusnih primjera: dodavanje natuknica iz liste riječi udžbenika (udžbenik Minna no Nihongo, udžbenik Tobira); dodavanje natuknica iz japansko-slovenskoga rječnika JaSlo; dodavanje idioma i poslovica; dodavanje vokabulara o određenoj temi

Iz ovih aktivnosti tijekom dvije godine nastalo je nekoliko leksikografskih pilot-projekata:

- Izrada japansko-hrvatskoga e-rječnika za neizvorne govornike japanskoga jezika

- Izrada specijaliziranih mrežnih korpusa o hrvatskome turizmu na japanskome jeziku

- Izrada specijaliziranoga japansko-hrvatskog e-rječnika s područja turizma, za koje je u planu ukomponirati ih u zajednički leksikografski projekt japansko-hrvatskoga e-rječnika za neizvorne govornike japanskoga, uključujući i specijaliziranu terminologiju iz turizma i drugih oblasti (Srdanović 2018, 2019, 2020).

U nastavku opisujemo način rada i rezultate ovih pilot-projekata.

\subsubsection{Japansko-hrvatski e-rječnik za neizvorne govornike japanskoga jezika (pilot-projekt)}

U prvoj fazi izrade rječnika studenti su istražili nekoliko postojećih rječnika japanskoga jezika kao potencijalni izvor za svoj mini rječnik te su ih odabrali prema temi svojega interesa. Prve akademske godine većina studenata posvetila se tematskome rječniku koji obuhvaća izraze prema različitim temama: vrijeme, izrazi u učionici, izrazi o osobnostima, zabava i sl., dok su druge akademske godine studenti međusobno podijelili lekcije udžbenika 
Tobira kako bi pokrili novi vokabular prisutan u tom udžbeniku japanskoga jezika na srednjoj razini.

Nakon izbora riječi, studenti su najprije pristupili unosu natuknica u tabličnome formatu (program Excel) s unaprijed definiranom mikrostrukturom rječnika, odnosno elementima koje će natuknica sadržavati. S obzirom na složenu prirodu japanskoga pisma (kanji, hiragana, katakana, romaji), bilo je potrebno unaprijed definirati pravila transkripcije i zapisivanja riječi $s$ primjerima. Isto tako, važan je korak i definiranje mikrostrukture rječnika, odnosno elemenata koje će natuknica sadržavati u okviru platforme Lexonomy, koje je najprije pripremio nastavnik, a zatim se kroz diskusiju sa studentima odlučivalo detaljnije o elementima kao što su vrste riječi, način zapisivanja natuknica, prijevoda, primjera i dr. Po tabličnome unosu natuknica studenata i provjeri sadržaja nastavnika, studenti su ručno unosili natuknice u uređivač Lexonomy unutar unaprijed pripremljene strukture rječnika.

U početnoj verziji mini rječnika popis i izgled natuknica izgleda kako je prikazano na slici $1 \mathrm{~s}$ primjerom natuknice za frazu kyoushitsu no souji wo suru 'pospremiti učionicu' koja pripada odabranoj temi izrazi u učionici. Slike 2 i 3 pokazuju primjer natuknice machiawaseru 'sastati se (s nekim)', dvodopunskoga neprijelaznog glagola, kako izgleda u sučelju (slika 2) te kako izgleda u formatu XML (Extensible Markup Language) unutar Lexonomyja. Format XML koristi se za tekstualno prikazivanje strukturiranih informacija.

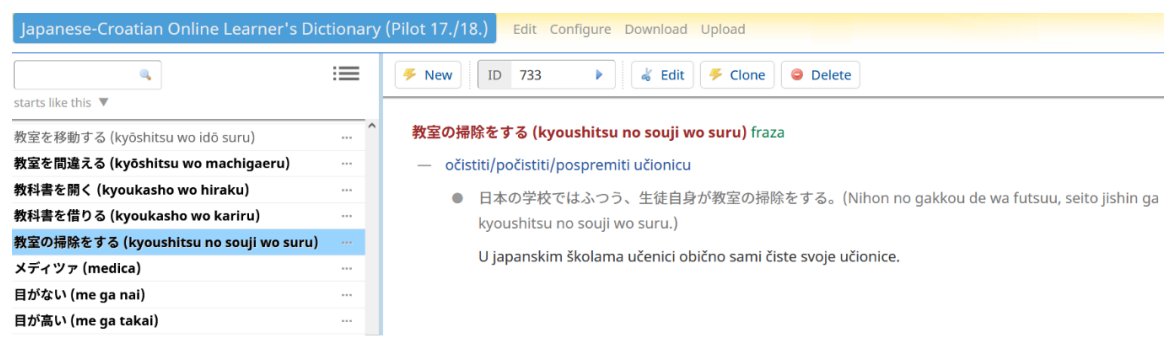

Slika 1. Rječnik unutar uređivača Lexonomy: popis i izgled natuknica 


\section{待ち合わせる (machiawaseru) gl-2 neprij.}

- sastati se (s nekim)

○フェで待ち合わせる (Kafe de machiawaseru)

\section{Sastati se u kafiću}

Slika 2. Primjer izgleda natuknice: machiawaseru 'sastati se (s nekim)'

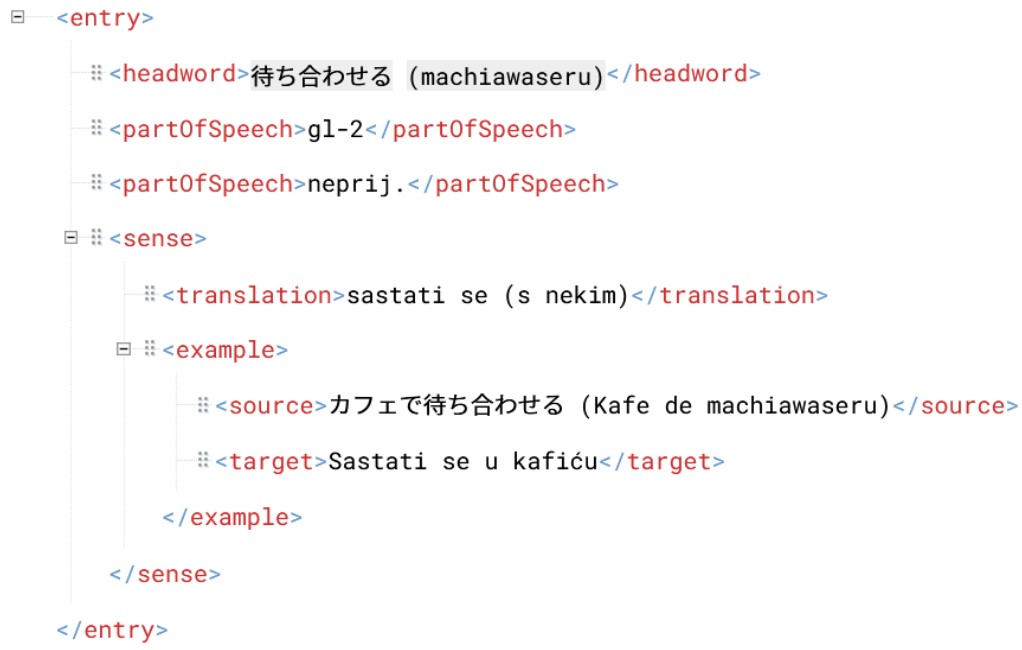

Slika 3. Primjer natuknice u formatu XML: machiawaseru 'sastati se'

Nakon ovoga pilot-projekta, dvojezični je rječnik postepeno nadopunjavan, a nadograđivane su upute studentima i mikrostruktura rječnika te su u međuvremenu obuhvaćene i druge informacije: o lekciji udžbenika, fonetski zapisi natuknica i primjera na japanskome slogovnom pismu kana i na latinici, varijacije, česti uzorak. Studenti i nastavnici pripremaju sadržaj u ujednačenom tabličnom formatu koji će se automatskim putem pretvoriti u XML strukturu budućega rječnika. U pripremi je izrada i opis modela e-rječnika koji će detaljno definirati mikrostrukturu i makrostrukturu budućega dvojezičnog japansko-hrvatskog rječnika s precizno razrađenom 
specifikacijom pretraživača rječnika. Tome će doprinijeti rezultati analize potreba učenika koje predstavljamo u drugome dijelu ovoga rada.

\subsubsection{Izrada specijaliziranih resursa na temu hrvatskoga turizma: web-korpusi i dvojezični rječnik (pilot-projekt)}

S povećanim brojem japanskih turista u užoj i široj regiji, javlja se i potreba educiranja novih kadrova u području turizma koji vladaju japanskim jezikom i dobri su poznavatelji japanske kulture. Iz toga proizlazi potreba za sistematiziranjem terminologije o hrvatskome turizmu na japanskome jeziku i izradom specijaliziranoga dvojezičnog japansko-hrvatskog rječnika za neizvorne govornike japanskoga jezika koji bi sadržavao lokalnu terminologiju potrebnu za vođenje tura i rad s japanskim turistima. Stoga se najprije krenulo s pilot-projektom izrade specijaliziranih mrežnih korpusa o hrvatskome turizmu na japanskome jeziku s ciljem korištenja tih resursa u izradi specijaliziranoga japansko-hrvatskog e-rječnika s područja turizma. U ovome poglavlju združeno predstavljamo ta dva tematski bliska pilotprojekta provedena u suradnji sa studentima.

Za izradu specijaliziranih mrežnih korpusa o hrvatskome turizmu na japanskome jeziku studenti su se prema detaljnim uputama koristili tehnologijom WebBootCat unutar platforme Sketch Engine te automatsko kreirali specijalizirane web-korpuse na temu hrvatskoga turizma na japanskome jeziku. U okviru aktivnosti prikupili su popis riječi /izraza na japanskome jeziku koji su povezani s hrvatskim turizmom u određenim gradovima, regijama, mjestima (npr. nazivi gradova, znamenitosti, tipična jela za određenu regiju i sl.), a zatim i popis različitih web-stranica. Detalji izrade korpusa i rezultati vrednovanja predstavljeni su u Srdanović (2020).

Specijalizirani internetski korpusi, bez obzira na svoju malu veličinu, pokazali su se korisni za prikupljanje vokabulara u području turizma te su postali dio specijaliziranoga rječnika unutar Lexonomyja. Slika 4 pokazuje primjer natuknice saruma 'sarma', dok slika 5 pokazuje primjer natuknice Barubimon 'Balbijev luk'. Obje natuknice sadrže autentične primjere na japanskome jeziku iz korpusa s prijevodima na hrvatski jezik. 


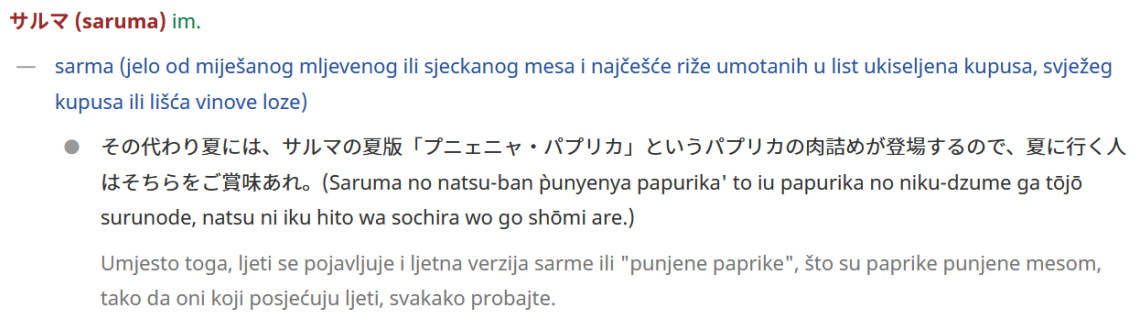

Slika 4. Natuknica saruma 'sarma' u specijaliziranome dvojezičnom rječniku

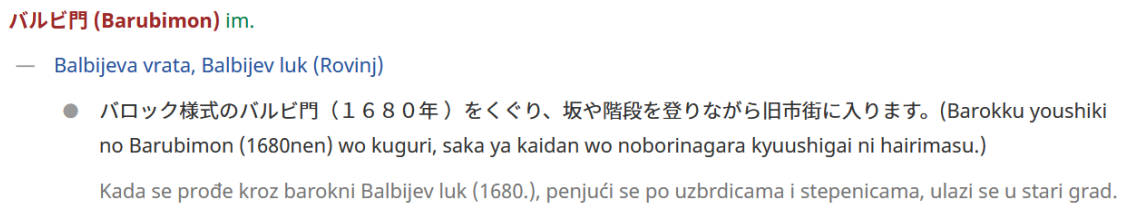

Slika 5. Natuknica Barubimon 'Balbijev luk' u specijaliziranome dvojezičnom rječniku

Rezultate opisanih pilot-projekata u planu je nadograditi i objediniti u budućem japansko-hrvatskom dvojezičnom e-rječniku.

\section{ANALIZA I REZULTATI ANKETE O KORIŠTENJU I IZRADI RJEČNIKA}

Anketa je provedena u vidu upitnika u pisanome obliku na studijskom programu japanologije na Filozofskome fakultetu Sveučilišta Jurja Dobrile u Puli u siječnju 2021. godine, a studenti ispitanici odgovorili su na postavljena pitanja za 10 do 15 minuta. Korišten alat za izradu ankete je Google obrazac u okviru kojega su postavljena pitanja u više formata: odabir jednoga odgovora, odabir više odgovora ili su ispitanici sami upisivali odgovor (od 1 do 5 redaka). Cilj je ankete bolje razumijevanje postojećih studentskih navika i tendencija u pogledu korištenja rječnika pri obavljanju različitih aktivnosti na japanskome jeziku, kao i spoznavanje potreba i želja studenata u vezi s budućim japansko-hrvatskim i/ili hrvatsko-japanskim e-rječnikom. 


\subsection{Specifični izazovi studenata japanskoga jezika s osvrtom na pismo}

Prije nego što pogledamo rezultate ankete, osvrnut ćemo se na složenost japanskoga pisma kao relevantan aspekt pri planiranju rječnika i propitivanju potreba njegovih korisnika. Standardno japansko pismo obuhvaća tri različite vrste grafema: dva fonetska pisma, hiraganu i katakanu, od po 46 grafema (ne računajući inačice s dijakritičkim znacima) i kanji znakove, logogramsko pismo koje se sastoji se od $2136^{10}$ grafema prema službenome popisu japanskoga Ministarstva obrazovanja iz 2010. Izvorni govornik japanskoga savlada pismo tijekom 12 godina obrazovanja. Iz perspektive korištenja rječnika, da bi se u engleskome rječniku našla natuknica although, potrebno je samo potražiti niz navedenih grafema u rječniku, pri čemu engleski jezik, hipotetski, nije potrebno ni poznavati. Za razliku od toga, traženje japanske natuknice zapisane učeniku nepoznatim grafemima nije trivijalno, jer, načelno govoreći, podrazumijeva prethodno nalaženje fonetskoga zapisa danoga znaka. Fonetski se zapis može naći u rječniku kanji znakova ${ }^{11}$ koji pruža drukčiji vid informacija od rječnika riječi, a u digitalnome okruženju studenti si pomažu dodatnim aplikacijama, npr. pop-up prozorčićima s informacijama o fonetskome zapisu grafema i riječi ili pak digitalnim čitačima. Ovaj alat može biti iznimno koristan pri učenju i usvajanju japanskoga jezika s jedne strane te pri razumijevanju tekstova i različitih digitalnih sadržaja na japanskome s druge strane.

\subsection{Ispitanici}

U anketi je sudjelovalo ukupno 35 studenata japanologije od kojih 18 studenata prve godine preddiplomskoga studija (51\%), 8 studenata prve godine diplomskoga studija, odnosno četvrte godine učenja (23\%), zatim 4 studenta treće (11\%) i 3 studenta druge godine preddiplomskoga studija (9\%), jedan apsolvent (3\%) i jedan bivši student preddiplomskoga studija, prvostupnik japanologije (3\%). Iz ovoga se vidi da su najmotiviraniji za sudjelovanje u anketi bili studenti na početku studija, kako preddiplomskoga tako i diplomskoga, jer je iz ove dvije grupe sudjelovalo $35 \%$, odnosno 36 $\%$ ukupnoga broja studenata na datoj godini.

10 Popis se može naći na stranici Agencije za kulturu Japana. https://www.bunka.go.jp/kokugo_ nihongo/sisaku/joho/joho/kijun/naikaku/kanji/index.html

11 Korištenje rječnika kanji znakova podrazumijeva znanje o broju, vrsti i redoslijedu poteza kojima se oni bilježe te kako su u rječniku organizirani pojedini ključni dijelovi kanji znakova. 


\subsection{0 vrstama rječnika i njihovom korištenju}

Na pitanje kojim se rječnicima ispitanici koriste, $92 \%$ (81 od 87) odgovora odnosilo se na e-rječnike, dok se 7 \% (6 od 87) odnosilo na tiskane. ${ }^{12}$ Nešto više odgovora odnosi se na rječnike na mobitelu (aplikacije i e-rječnike na internetu skupa) (40 \%) od e-rječnika na računalu (38 \%), dok ostali odgovori obuhvaćaju korištenje e-rječnicima u obliku pop-up dodataka i mrežnih servera s puno različitih rječnika. Ovi rezultati podudaraju se s općim trendom porasta korištenja digitalnih sadržaja u odnosu na tiskane, kao i rezultatima srodnih anketa o korištenju digitalnih resursa provedenih kod učenika japanskoga jezika (npr. Suzuki 2012, Toyoda 2016). Toyoda (2016) je ukazala na brze promjene trendova s obzirom na povećanu dostupnost interneta, korištenje pametnim telefonima i dostupnost e-rječnika te je usporedila rezultate Suzukijine analize (2012) o korištenju e-rječnicima i drugim digitalnim alatima kod neizvornih govornika japanskoga jezika, kada su prijenosni rječnici (dlanovnici) bili popularni, s rezultatima iz 2015. godine kada se uočava znatni porast u korištenju e-rječnicima, prije svega na mobilnim telefonima, a zatim i na mrežnim stranicama.

Za aktivnosti povezane sjapanskim jezikom najveći postotak ispitanika koristi se dvojezičnim japansko-engleskim (71 \%) i englesko-japanskim rječnikom (47 \%). Značajno mjesto ovdje zauzima i rječnik kanji znakova s 38 \%. Uz to, određeni broj studenata viših godina koristi se jednojezičnim japanskim rječnikom (15\%). Studenti navode korištenje sljedećim e-rječnicima: Jisho (21), Takoboto (5), Goo (3), Yomiwa (3), Tangorin (5), Akebi, Kotobank, JED Japanese Dictionary, Weblio. Jisho je najpopularnija rječnička aplikacija s čak 14 ispitanika koji su naveli da se njome najčešće koriste. Od rječnika kanji znakova, studenti koriste IMI, Jitenon, Study kanji, Kanji tree. Kako je prikazano na slici 6, 68 \% ispitanika koristi se rječnikom nekoliko puta dnevno, dok se 29 $\%$ koristi nekoliko puta tjedno, što je svakako značajan podatak koji ukazuje na potrebu studenata za ovim digitalnim resursima. 
34 odgovora

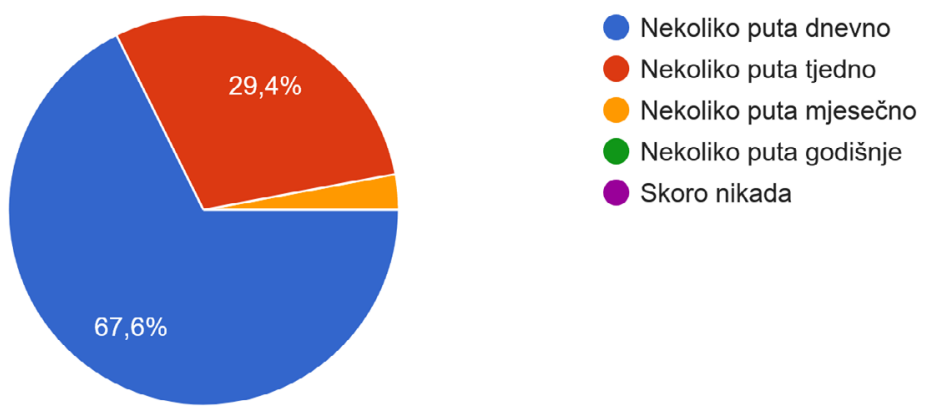

Slika 6. Koliko često se studenti koriste rječnicima

Značenje nepoznatoga kanjija studenti rado pronalaze pomoću pop-up rječnika (npr. YomiChan, Rikaikun) koji su integrirani alati u mrežnim pretraživačima. Pop-up rječnik funkcionira tako što se pomicanjem miša preko jednoga ili niza grafema, dobije obilje korisnih podataka, prije svega fonetski zapis grafema ili riječi (kako se grafem ili riječ čita). Alat najprije određuje gdje je granica riječi, jer to u japanskome pismu nije određeno razmakom između riječi, zatim navodi fonetski zapis (tzv. čitanje), vrstu riječi, značenje na engleskome i drugo. Studentima je od pomoći optički čitač (skener) pomoću kojega se može saznati kako glasi fonetski zapis nepoznatoga grafema, kao i Google prevoditelj. Od aplikacija također su spomenute Duolingo, Memrise i Quizlet, a od stranica za nalaženje primjera Tatoeba i Reversocontext.

\subsubsection{Korisne informacije u rječnicima}

Anketa otkriva koje informacije studenti navode kao posebno korisne u postojećim rječnicima, što je prikazano u tablici 1. Osim značenja riječi, prije svega s opisom na ciljanome i izvornome jeziku, a zatim i ekvivalentima na ciljanome jeziku, studentima su visoko na listi prioriteta fonetski zapis kanji znakova, detalji o konjugacijskim oblicima riječi (u japanskome su to glagoli, pomoćni glagoli i pridjevi), vrstama riječi, frekventnosti, JLPT ${ }^{13}$ razini, te zvučniizgovor riječi. Primjeri upotrebe na izvornome jeziku isto zauzimaju

13 JLPT (Japanese Language Proficiency Test) 'Test znanja japanskog jezika' 
značajno mjesto, no raspršeni su na tri ponuđena odgovora ${ }^{14}$ što se potvrđuje slobodnim odgovorima i odgovorima na pitanje o najvažnijoj informaciji u rječnicima gdje su po značaju na drugome mjestu nakon značenja riječi (vidi tablicu 2). Zatim slijede stilske karakteristike riječi (koristi li se riječ u formalnome ili neformalnome stilu), navođenje sinonima i antonima, kolokacije te glagolske dopune, ali i opisi termina karakterističnih za japansku kulturu. Tablica 2 pokazuje za što se studenti opredjeljuju kao najkorisnije informacije u rječnicima. Studenti navode upravo značenje (14 od 31), primjere (11), fonetski zapis (7), frekvenciju (5), sinonime (3), ali i slike, izgovor, vrstu i oblike riječi.

Tablica 1. Korisne informacije u postojećim rječnicima (po redoslijedu značaja)

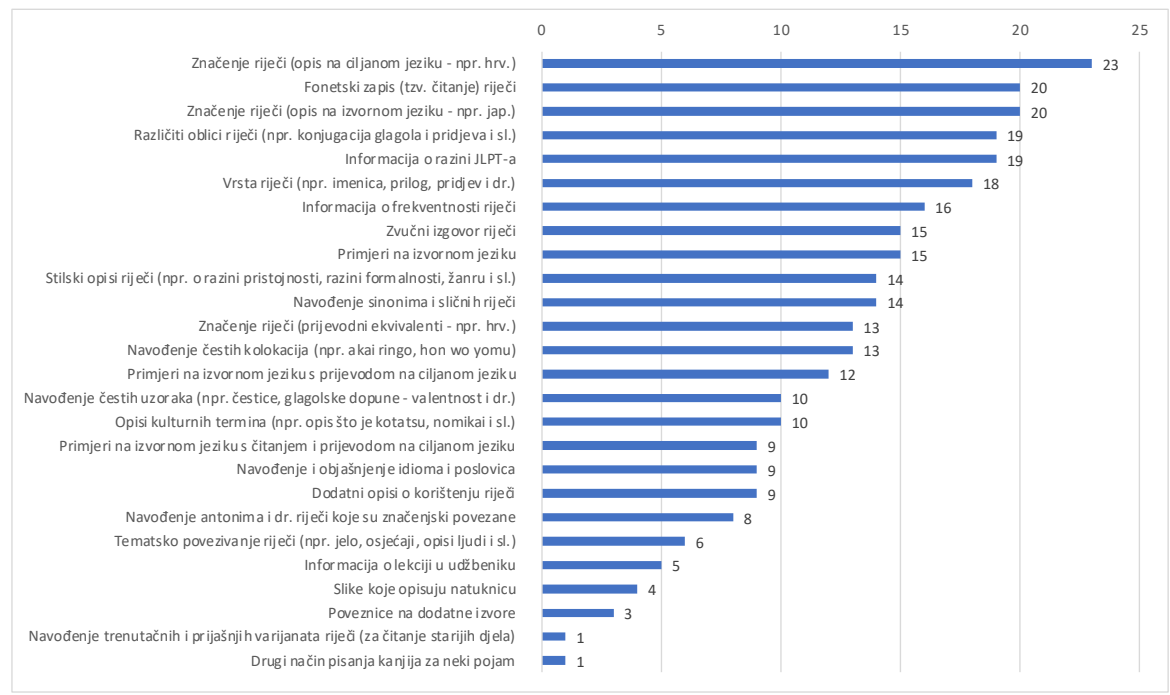

$14 \mathrm{U}$ anketi su ponuđeni odgovori „Primjeri na izvornom jeziku“, „Primjeri na izvornom jeziku s prijevodom na ciljanom jeziku“ $i$ „Primjeri na izvornom jeziku s čitanjem i prijevodom na ciljanom jeziku“. Svaki je od ponuđenih odgovora dao prosječno visoke rezultate što pretpostavlja raspršenost odgovora. 
Tablica 2. Studentima najkorisnije informacije u rječnicima

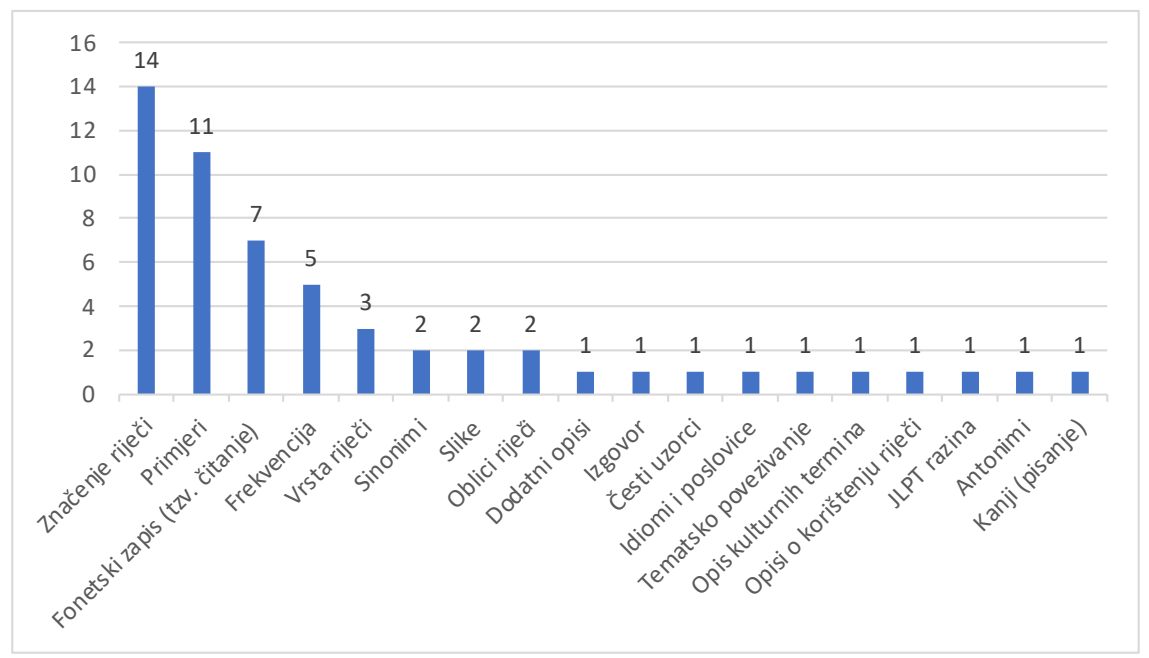

\subsubsection{Nedostatne informacije u rječnicima i druge poteškoće}

Na pitanje o informacijama koje studentima nedostaju u rječnicima kojima se koriste, studenti navode nedostatak odgovarajućih primjera jer ih je malo ili su preteški; zatim, studenti žele objašnjenja kako se razlikuju riječi koje se izgovaraju jednako, imaju primarno značenje isto, a pišu se različitim kanji znakovima. ${ }^{15}$ Dalje, iskazana je potreba za podatcima o razini formalnosti riječi te u kojim se situacijama riječ koristi. Studenti primjećuju da jednoj riječi, na hrvatskome ili engleskome, odgovaraju različite japanske, ali bi željeli znati koja ima koju značenjsku nijansu i kada se koristi. Studenti također navode da nedostaju onomatopeje, idiomi i poslovice, etimologija i sleng.

Kao probleme na koje nailaze pri korištenju postojećih rječnika i alata, studenti navode nepotpunost i netočnost informacija, nepostojanje imena prefektura, gradova, ulica, vlastitih imena, nepostojanje konjugacije, slabu pokrivenost onomatopeja i idioma kao i njihovo objašnjenje i prijevod na engleskome, a ne hrvatskome, što sve otežava brzo i potpuno razumijevanje i pronalaženje informacija. Uz to, više se puta navodi nedovoljan broj korisnih primjera iz kojih se može vidjeti upotreba riječi u različitim situacijama,

15 Pridjev katai 'tvrd, čvrst' može se zabilježiti na tri različita načina: 固い, 堅い i 硬い. Prvi se koristi većinom u apstraktnom kontekstu, npr. u kolokaciji katai shinnen 'čvrsto uvjerenje' suprotno od 'labav'; drugi se koristi u smislu 'solidan, pouzdan' suprotno od 'krhak', kao u katai mamori 'čvrsta obrana'; dok se treći koristi u fizičkom smislu tvrdoće suprotno od 'mekan', npr. u katai ishi 'tvrd kamen'. 
koristi li se riječ u formalnome ili neformalnome stilu i slično, što naročito vrijedi za manje frekventne riječi. S druge strane, problem je i kad dobiju previše rezultata koji mogu biti zbunjujući i nepovezani. Nekoliko odgovora odnosi se na mrežne alate za prepoznavanje kanjija „nacrtanih“ pomoću računala, kada alat ne prepozna nacrtani grafem uslijed nepravilnoga crtanja kanji poteza ili starijih oblika grafema. U slučaju ovih problema studenti traže kanji preko radikala.

\subsubsection{Aktivnosti uz rječnik}

Studentima rječnici služe u različitim aktivnostima kao što je prikazano u tablici 3. Od navedenih aktivnosti studenti se najčešće koriste rječnikom pri učenju vokabulara (74 \%, 26 od 35 studenata) i savladavanju novoga gradiva ( $66 \%$, 23 studenata). Često ga koriste i za aktivnosti prevođenja ${ }^{16}$, što podrazumijeva pronalaženje značenja japanskih riječi na hrvatskome (66 \%, 23 studenata) i prevođenje riječi s hrvatskoga na japanski (51 \%). Osim toga, česte aktivnosti uz rječnik jesu čitanje na japanskome (57 \%) i pisanje na japanskome (57 \%), priprema govora na japanskome (43\%) ali i za druge, npr. korištenje rječnikom pri slušanju muzike, gledanju filmova i animea, praćenju igrica i čitanju mangi. Slobodni odgovori u anketi otkrili su da rječnik koriste i za pisanje sastavaka i drugih zadaća.

Tablica 3. Aktivnosti u kojima se studenti koriste rječnikom

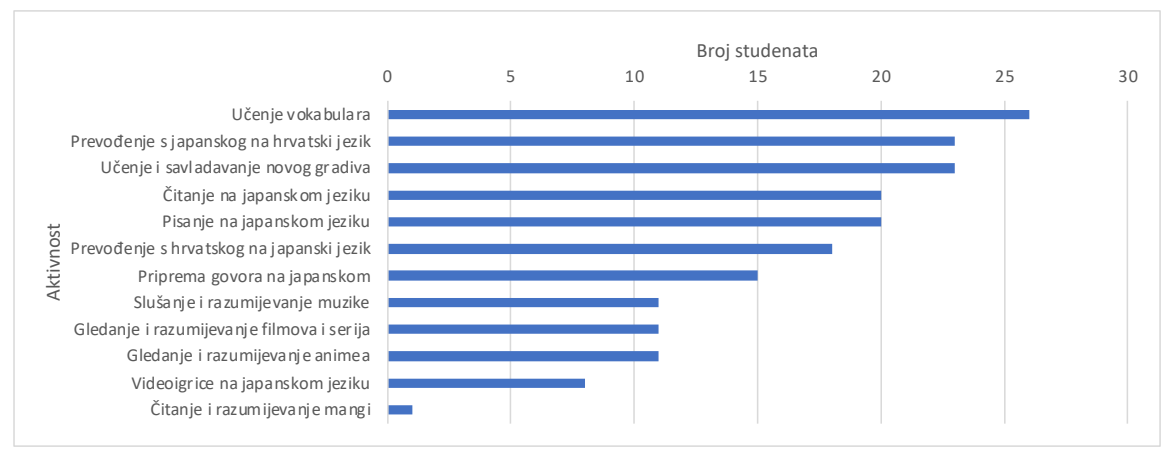

Neki studenti navode da se koriste rječnikom za utvrđivanje (pamćenje) riječi, posebno kroz primjere jer im pomažu zapamtiti kako se data riječ koristi, u kojim situacijama i u kojemu govornom stilu. Jedan ispitanik navodi

16 Ova se aktivnost većinom odnosi na prevođenje tekstova iz udžbenika i drugih zadanih materijala, ili sadržaja od posebnoga interesa studenata. 
da mu, kada uči izravno iz rječnika, najviše pomaže navođenje sinonima i antonima datoga pojma, a drugi navodi korisnost vlastitih zbirki riječi. Što se tiče načina kako usvajaju nove riječi, veliki broj studenata navodi da ponavlja dok ne nauči, neki pomoću udžbenika, a neki kroz pjesme, uporabu u komunikaciji (dopisivanje s izvornim govornicima) ili ispisivanjem riječi u bilježnicu. Zatim, neki bilježe riječi na tzv. flashcard aplikacijama za naknadno preslušavanje. Studenti navode da najbolje uče riječi u kontekstu različitih sadržaja te da kod nepoznavanja riječi u rječniku traže značenje i način korištenja. Riječi usvajaju i kroz igrice, anime i mange, odnosno sadržaje koji ih motiviraju da upamte riječ, te navode da se u tim aktivnostima također koriste rječnikom za bolje razumijevanje i učenje nepoznatih riječi. S druge strane, ispitanici velikom većinom navode da nema informacija koje su u rječniku suvišne.

\subsection{4. Željene informacije i svrha budućega rječnika}

Od niza navedenih opcija u upitniku studenti su najčešće odabrali sljedeće informacije koje žele vidjeti u budućem japansko-hrvatskom bilingvalnom rječniku: opis značenja riječi ( $67 \%, 22$ od 33 studenata), fonetski zapis kanji znakova (58 \%, 19 studenata), navođenje sinonima i sličnih riječi (58 \%, 19 studenata), podatke o vrsti riječi ( $55 \%$ ), različite oblike promjenjivih riječi (52\%), stilski opis riječi (npr. o razini pristojnosti i formalnosti, registru i sl.) (52\%), primjere na izvornome jeziku s fonetskim zapisom i prijevodom na ciljani jezik (48\%) i primjere na izvornome jeziku s prijevodom na ciljani jezik (45\%). Uz to, čest su odabir informacije o lekciji u kojoj se javlja data riječ, JLPT razini, frekvenciji, zatim tematsko povezivanje riječi, česte kolokacije, glagolske dopune, ali i opisi pojmova specifičnih za japansku kulturu, kao i slike koje opisuju natuknicu uz poveznice na dodatne izvore.

Što se tiče aktivnosti u kojima bi im japansko-hrvatski rječnik služio, rezultati ankete pokazuju da bi se studenti koristili njime prije svega kao pomoć pri recepciji sadržaja, dok je produkcija spomenuta u nešto manjem obujmu. U najvećem broju odgovora navodi se da bi rječnik bio koristan za učenje japanskoga jezika (12) što se odnosi na pronalaženje i učenje novih riječi, ponavljanje, uvježbavanje, odnosno savladavanje gradiva. Jaku vezu između učenja i rječnika jedan od ispitanika opisao je iskazom „rječnik je nešto što je neizostavno za učenje ikakvog jezika“. Znatan broj odgovora odnosi se na svrhu prevođenja tekstova (7), prije svega s japanskoga na hrvatski jezik, ali i obrnuto. Navodi se da rječnik može pomoći prisjetiti se odgovarajućih hrvatskih ekvivalenata koji pri samome prevođenju ne 
padaju na pamet. Uz to, navodi se traženje značenja nepoznatih riječi iz udžbenika, razumijevanje lekcija u udžbenicima, ponavljanje vokabulara za ispite, razumijevanje japanske glazbe, knjiga, igrica, i drugih medija, razumijevanje pojmova karakterističnih za japansku kulturu kao kotatsu, nomikai i dr. Pogodan bi bio kao podrška pri praćenju nastave te čitanju knjiga, ali i pisanju zadaće, radova i sastavaka na japanskome jeziku. Koristio bi im, dakle, za sve ono za što trenutačno koriste druge rječnike, s tim što bi imali značenja i objašnjenja na materinskome jeziku. Relevantno je spomenuti mišljenje nekoliko ispitanika da bi takav rječnik koristio kao nadopuna drugim rječnicima te je za očekivati paralelno korištenje više alata i rječnika ovisno o potrebama i aktivnostima studenata.

\subsubsection{Prijedlozi i želje za novi rječnik}

Što se pretraživača tiče, studenti ističu važnost jednostavnosti korisničkoga sučelja. ${ }^{17}$ Žele da to bude mobilna aplikacija i da se mogu pretraživati riječi na oba jezika. Predlažu poveznice na riječi unutar primjera, objašnjenja tako da se jednim klikom može doći na tu riječ. Predlaže se mogućnost izvoza podataka (popisa riječi). Zatim kao i mogućnost unošenja zvučnoga zapisa i njegovo pretvaranje u zapis japanskim pismom. Također, željeli bi imati u okviru rječnika i što više primjera s prijevodima. Što se tiče prijedloga vezano za pismo, neki bi studenti voljeli da postoji mogućnost skeniranja teksta, po ugledu na Google prevoditelj, radi trenutačnoga dobivanja fonetskoga zapisa i značenja, dok drugi predlažu da u rječnik bude integrirana mogućnost upisa kanji znakova redoslijedom kojim se oni po pravilu pišu, što ipak podrazumijeva određenu razinu poznavanja japanskoga pisma (za razliku od prve opcije).

Iz perspektive načina pretraživanja, studenti bi željeli imati mogućnost pretraživanja fonetskoga zapisa (kana i latinica) i kanji znakova; zatim po JLPT razinama, po lekcijama udžbenika, po značenju, po odlikama stila te po učestalosti upotrebe. Također navode i tematsko pretraživanje srodnih pojmova i pretraživanje u različitim konjugacijskim oblicima.

Prijedlozi studenata o funkcionalnostima u japansko-hrvatskome rječniku kao i opisane vizije o aplikaciji budućnosti izvedive su s gledišta tehnoloških inovacija. Rezultat su doticaja studenata s različitim

17 Navodi se da je jednostavnost jedna od prednosti aplikacije Jisho u odnosu na Tangorin. 
postojećim resursima kao i njihovih realnih potreba te će biti razmotreni s obzirom na prioritete i mogućnosti u izradi budućega rječnika.

\subsubsection{0 sudjelovanju studenata u izradi rječnika}

Velika većina ispitanika (94\%) smatra da bi studenti mogli pomoći u izradi rječnika. Studenti vide sebe u sastavljanju popisa vokabulara iz udžbenika radi sistematizacije stečenoga znanja, smatraju da bi mogli doprinijeti opisivanju značenja riječi te sastavljanju primjera uz nadzor profesora. Student diplomskoga studija želio bi doprinijeti opisu etimologije, navođenjem sinonima i podataka o učestalosti. Neki bi rado pomogli oko web i grafičkog dizajna, formatiranja i testiranja.

\subsubsection{0 drugim alatima i aplikacijama}

Od alata koji im pomažu u produkciji japanskoga jezika studenti navode aplikaciju Duolingo, spomenuti pop-up alat Rikaichan, u prvim fazama učenja kanji znakova koristan je bio KanjiStudy, zatim web-stranice za rješavanje zadataka Marugoto i J-learning, baze podataka s primjerima izvornika na japanskome i prijevoda iste rečenice na engleski, kao što su Reverso i Tatoeba te Google prevoditelj. ${ }^{18}$

\subsubsection{Aplikacija budućnosti}

Ispitanici u svojoj viziji aplikacije budućnosti izražavaju želju za alatima koji će im omogućiti da savladavaju gradivo po lekcijama, da alat pamti riječi koje su prije tražili i da sadrži mrežne igre u svrhu učenja i utvrđivanja gradiva, posebno u početnim fazama učenja, što bi predstavljalo takozvanu gemifikaciju (Kallas i dr. 2019: 529). Na višim godinama studenti češće ponavljaju vokabular uz flash kartice. Nadalje, često se navode funkcije koje će im omogućiti skeniranje teksta radi lakšega pretraživanja kanji znakova. Osim sadržaja koje nalaze u postojećim rječnicima kojima se služe, i informacija koje studenti žele u budućem rječniku, studenti spominju da bi voljeli imati na raspolaganju pop-up alat nalik Rikaikunu na hrvatskome. Također navode da bi im od pomoći bio i izgovor riječi te slike kao ilustracije pojmova; koristili bi se i videozapisima u kojima se vidi izgovor riječi, mogućnost povezivanja s postojećim bazama podataka i izvorima na mrežnim stranicama.

18 Za detaljniju analizu mobilnih i multimedijalnih resursa za učenike japanskoga jezika vidi Dangubić i Srdanović (2021). 


\subsection{DISKUSIJA}

Anketa je pokazala da se dio studenata rječnicima i drugim jezičnim alatima koristi upravo u svrhu učenja jezika u smislu jačanja jezičnih kompetencija, dakle vlastitoga znanja koje se može pokazati neovisno o raspoloživosti digitalnih resursa. Njihove želje i očekivanja prema budućemu japanskohrvatskom bilingvalnom rječniku također su usmjerena u tom pravcu, a povezani su i s njihovom trenutačnom razinom znanja. Primjerice, student druge godine želio bi rječnik koji sadrži mogućnost učenja i ponavljanja kroz interaktivne edukativne igre, npr. razne križaljke ili povezivanje riječi s objašnjenjima. U sličnom duhu, student prve godine piše da bi njegova idealna aplikacija olakšavala učenje organizacijom riječi po lekcijama u udžbeniku te bi omogućavala najprije usvajanje samih riječi, a potom grafema kojima se zapisuju.

S druge strane, rezultati ankete sugeriraju da se dio studenata jezičnim alatima koristi s primarnim ciljem čim boljeg razumijevanja sadržaja na japanskome. Ti alati mogu biti od velike pomoći pri učenju i saznavanju različitih sadržaja napisanih na japanskome jeziku, ali ovisno o načinu korištenja ne moraju nužno dovesti do jačanja jezičnih kompetencija. Jedan ispitanik izrazio je mišljenje da bi bilo „savršeno kad bi postojao mrežni alat koji bi efikasno i kvalitetno mogao prevoditi japanske književne tekstove s metaforama i stilskim figurama tako da prijevod izgleda što prirodnije na jeziku na koji se tekst prevodi." Student prve godine želi aplikaciju koja bi mogla „direktno prevoditi govor”, no odmah zaključuje: „Ali onda bi manje ljudi učilo jezike jer ih ne bi bilo više potrebno znati."

Ova dva pristupa korištenju mrežnih jezičnih resursa odražavaju se i u pristupu učenju pisma. Dio ispitanika navodi da im smeta što se pri korištenju aplikacija za crtanje kanjija (što je potrebno kad se naiđe na nepoznati grafem) mora poštovati redoslijed poteza jer inače aplikacija taj kanji ne prepoznaje. To pokazuje želju studenata da dođu do fonetskoga zapisa grafema bez poznavanja pravilnoga pisanja japanskoga pisma, odnosno redoslijeda poteza kanji znakova. ${ }^{19} \mathrm{U}$ vrijeme eksponencijalnoga razvoja digitalne tehnologije i posebice jezičnih tehnologija, očekivanje da se do značenja riječi ili teksta dođe bez posezanja za rječnikom nisu nimalo neobična niti neočekivana, naprotiv. Međutim, ako je cilj jačanje jezičnih kompetencija, neophodno je

19 Kanji znakovi uče se tako što se ispisuju utvrđenim redoslijedom. Nakon savladanih kanji znakova na početnoj razini, studenti mogu steći sposobnost prepoznavanja ključnog dijela kanji znaka (radikal) te prebrojiti sve poteze, što im je potrebno da bi našli riječ. 
poznavanje kanji znakova, uključujući i redoslijed poteza pri pisanju. S druge strane, neki ispitanici navode da žele da im novi japansko-hrvatski rječnik omogući unos kanji znakova upravo po redoslijedu poteza kako se kanji treba pisati da bi ga prije naučili i bolje utvrdili. Ovaj drugi pristup upravo pokazuje želju za jačanjem jezičnih kompetencija koje će postojati i izvan digitalnoga okruženja.

U kontekstu e-leksikografije i naprednih tehnologija rezultati ankete mogu se uzeti kao polazište za propitivanje dostupnih resursa (npr. korpusi japanskoga i hrvatskoga jezika, tehnologije skeniranja kanjija, tehnologije poluautomatskoga izvlačenja termina, kolokacija, primjera i drugih leksikografskih podataka iz korpusa, postojećih jednojezičnih i dvojezičnih e-rječnika japanskoga jezika) koji mogu automatizacijom ili poluautomatizacijom olakšati buduću izgradnju e-rječnika s jedne strane, te ga s druge strane obogatiti povezivanjem s drugim mrežnim resursima.

\section{ZAKLJUČAK}

U ovome radu predstavili smo nekoliko leksikografskih pilot-projekata provedenih sa studentima preddiplomskoga studija japanologije na Sveučilištu Jurja Dobrile u Puli u okviru kolegija Uvod u leksikologiju i leksikografiju. Uključivanje studenata u proces izrade mini rječnika pokazalo se kao dobra metoda za stručnu obuku u analizi i opisu jezika pomoću suvremenih tehnologija (npr. korpusa, platforme za pretraživanje korpusa i izradu rječnika, izrade i vrednovanja primjera za rječnik ${ }^{20}$. Osim toga, njegova važnost uočava se i u procesu učenja vokabulara kao i za izobrazbu novih stručnjaka za rad u turizmu na japanskome jeziku. Ujedno su dobivene smjernice za planiranje modela cjelovitijega i potpunijega dvojezičnog e-rječnika.

U drugome dijelu rada predstavljeni su rezultati provedene ankete kojom propitujemo navike studenata u korištenju elektroničkih resursa i e-rječnika, kao i njihove potrebe za budućim rječnikom, što predstavlja važan prvi korak u planiranju i osmišljavanju dizajna rječnika za neizvorne govornike. U poveznici s rezultatima ankete u kojoj uočavamo motiviranost i želju studenta za suradnjom u izradi rječnika, te u skladu s leksikografskim preporukama o uključivanju akademske zajednice i korisnika rječnika, kao i razvojem

20 Vidi Srdanović $(2019,2020)$. 
crowdsourcing tehnologija, zaključujemo da je aktivno uključivanje studenata u proces dizajniranja i izradu rječnika ispravan i poželjan pristup.

Iz rezultata provedene ankete kod znatnoga broja studenta vidljiva je velika motiviranost usmjerena na savladavanje i dublje poznavanje japanskoga jezika i pisma te u tome vide rječnik kao sredstvo koje im može biti od pomoći. Rezultati ankete pokazuju da se gotovo $70 \%$ studenata svakodnevno koristi rječnicima i alatima. Isto tako, uz pomoć informacija u određenoga broja ispitanika uočava se usmjerenost na sadržaj pri čemu je rječnik ili neki budući željeni alat sredstvo za bolje razumijevanje i upoznavanje konkretnih sadržaja napisanih na japanskome jeziku.

U ovome istraživanju došli smo do korisnih podataka o studentskim navikama, interesima, željama i potrebama, kako ih sami studenti percipiraju, s osvrtom na leksikografsku, edukacijsku i informacijsko-tehnološku praksu, što je prvi značajan korak u planiranju i pripremi rječnika. Sljedeći je korak izrada dizajna detaljnim planiranjem makrostrukture i mikrostrukture budućega japansko-hrvatskog dvojezičnog e-rječnika, pri čemu su rezultati ovoga istraživanja od ključnoga značaja. 


\section{LITERATURA}

ATKINS 2002

Beryl T. Atkins, „Bilingual dictionaries: past,present and future“, Lexicography and Natural Language Processing. A Festschrift in Honour of B. T. S. Atkins, Grenoble: EURALEX, 2002.

DANGUBIĆ - SRDANOVIĆ 2021

Sara Dangubić, Irena Srdanović, „Evaluation of mobile and multimedia resources targeted at Japanese language learners",CASTEL/J2021, 255-260.

ERJAVEC i dr. 2006

Tomaž Erjavec, Kristina Hmeljak Sangawa, Irena Srdanović, „jaSlo, A Japanese-Slovene Learners' Dictionary: Methods for Dictionary Enhancement", Proceedings of the 12th EURALEX International Congress, Turin 2006.

HMELJAK SANGAWA i dr. 2009

Kristina Hmeljak Sangawa, Tomaž Erjavec, Yoshiko Kawamura, „Automated collection of Japanese word usage examples from a parallel and a monolingual corpus", eLexicography in the 21st century: new challenges, new applications: Proceedings of eLex, Presses Universitaires de Louvain, Louvain 2009., 137-147.

KILGARIFF i dr. 2004

Adam Kilgarriff, Pavel Rychly, Pavel Smrž, David Tugwell, „The Sketch Engine“, Proc. Euralex, Lorient 2004., 105-116.

KALLAS i dr. 2019

Jelena Kallas, Svetla Koeva, Iztok Kosem, Margit Langemets, Carole Tiberius, „Lexicographic Practices in Europe: A Survey of User Needs (31. 1. 2019)": https://ec.europa.eu/research/participants/documents/ downloadPublic?documentIds=080166e5c120f129\&appId=PPGMS

KUNZMANN-MULLER 2001

Barbara Kunzmann-Muller, „Dvojezična leksikografija i manji jezici“, Rasprave Instituta za hrvatski jezik i jezikoslovlje, 27, 2001., 161-175.

MARKOVIĆ i dr. 2018

Ljiljana Marković, Divna Tričković, Irena Srdanović, „Udžbenikjapanskoga jezika Ippo Ippo: Glavna knjiga", Sveučilište Jurja Dobrile u Puli, Pula 2018. MĚCHURA 2017

Michal B. Měchura, „Introducing Lexonomy: an open-source dictionary writing and publishing system' in Electronic Lexicography in the 21st Century: Lexicography from Scratch. Proceedings of the eLex 2017 conference, 19-21 September 2017, Leiden, The Netherlands, 2017.

PRENSKY 2001 
Marc Prensky, „Digital Natives, Digital Immigrants Part 1”, On the Horizon, Vol. 9 No. 5, 1-6, 2001.

\section{https://doi.org/10.1108/10748120110424816}

\section{PRĆIĆ 2020}

Tvrtko Prćić, „Teaching Lexicography as a University Course: Theoretical, Practical and Critical Considerations", Lexikos 30, 2020., 1-28.

\section{https://dx.doi.org/10.5788/30-1-1597}

\section{SINCLAIR 1984}

John Sinclair, „Lexicography as an Academic Subject“, Hartmann, R.R.K. (Ed.), LEX'eter '83 Proceedings. Papers from the International Conference on Lexicography at Exeter: 3-12. Tübingen: Max Niemeyer, 1984.

\section{SPITZER 2018}

Manfred Spitzer, „Digitalna demencija: kako mi i naša djeca silazimo s uma”. Zagreb 2018.

SRDANOVIĆ i dr. 2008

Irena Srdanović, Tomaž Erjavec, Adam Kilgarriff, „A web corpus and word sketches for Japanese", Shizen gengo shori Uournal of Natural Language Processing), 15, 2, Tokyo 2008., 137-159. (reprinted in Information and Media Technologies 3, 3, 529-551.)

SRDANOVIĆ i dr. 2013

Irena Srdanović, Vid Suchomel, Toshinobu Ogiso, Adam Kilgarriff, ,Japanese Language Lexical and Grammatical Profiling Using the Web Corpus JpTenTen", Proceeding of the 3rd Japanese corpus linguistics workshop, NINJAL, Tokyo 2013., 229-238.

SRDANOVIĆ - Kosem 2016

Irena Srdanović, Iztok Kosem, „GDEX for Japanese: Automatic extraction of good dictionary examples", GLOBALEX 2016 Lexicographic Resources for Human Language Technology, Portorož 2016., 57-64.

SRDANOVIĆ 2018

Irena Srdanović, „Engaging Students in Creating Bilingual Online Learner's Dictionaries: General and Specializing in Tourism", International Symposium Japanese Language Learning for New Generations: Book of Abstracts, Pula 2018.

\section{SRDANOVIĆ 2019}

Irena Srdanović, „Odabir prikladnih primjera za učenički rječnik: značajke GDEX-a za japanski jezik i mogućnosti uporabe“, Tabula: časopis Filozofskog fakulteta 16, 2019, 175-197. 
SRDANOVIĆ 2020

Irena Srdanović, „Od specijaliziranih mrežnih korpusa do rječnika za neizvorne govornike." Rasprave: Časopis Instituta za hrvatski jezik $i$ jezikoslovlje, 46 (2), 2020., 1059-1083.

https://doi.org/10.31724/rihjj.46.2.31.

SUZUKI 2012

Tomomi Suzuki ( 鈴木智美 ), „Survey on Japanese language learners' dictionary use" (留学生の辞書使用についての実態調査〜東京外国語 大学で学ぶ留学生へのアンケート調査の結果と分析), Tokyo University of Foreign Studies Journal (東京外国語大学論集), 38, 2012., 1-21.

TOYODA 2016

Etsuko Toyoda, „Usage and efficacy of electronic dictionaries for a language without word boundaries", The EUROCALL Review, 24/2, 2016., 13-23.

UEYAMA - SRDANOVIĆ 2018

Motoko Ueyama, Irena Srdanović (eds.), „Digital Resources for Learning Japanese“, Bognona University Press, Bologna 2018.

YAMASAKI-VUKELIĆ 2006

Hiroshi Yamasaki-Vukelić, "Japansko-hrvatski, hrvatsko-japanski rječnik“, Zagreb 2006.

\section{MREŽNI IZVORI}

Reading Tutor (日本語読解学習支援システムリーディングチュウ太):

https://chuta.cegloc.tsukuba.ac.jp/

Villa Vigoni thesis on lexicography (Villa Vigono teze o leksikografiji):

https://www.emlex.phil.fau.eu/about-us/publications/other/

JEV (日本語教育語彙表)

https://jreadability.net/jev/ 


\section{SUMMARY}

\section{Participation of Japanese language students in lexicographic activities and planning of a bilingual e-dictionary}

Most students of Japanese Studies at the Juraj Dobrila University of Pula are digital natives, and their digital literacy is further enhanced by the availability of a large number of Japanese language resources, both in the form of mobile and smartphone applications and in the form of websites, computer assisted language learning tools and other multimedia tools. As most of these resources use Japanese and English language, it has been noticed that the students need bilingual Japanese-Croatian dictionaries and other Japanese language resources with explanations, translations, and additional information in their native language as well. The aim of this paper is twofold: 1) to present pilot projects for the development of JapaneseCroatian bilingual e-dictionaries in cooperation with students and teachers of Juraj Dobrila University of Pula and with the help of an open platform for e-dictionary development Lexonomy (Měchura 2017), 2) to analyze the survey and identify trends in the use of existing dictionaries, electronic dictionaries and other resources as well as the needs of Japanese language students for the planned more extensive Japanese-Croatian e-dictionary with an objective to develop a model of that e-dictionary.

Keywords: Japanese-Croatian bilingual dictionary, e-dictionary, survey, digital resources, students of Japanese studies 